\title{
Receptor-recycling model of clearance and distribution of insulin in the perfused mouse liver
}

\author{
H. Sato, T. Terasaki, H. Mizuguchi, K. Okumura and A. Tsuji \\ Faculty of Pharmaceutical Sciences, Kanazawa University, Takara-machi, Kanazawa, Japan
}

\begin{abstract}
Summary. After perfusion of mouse livers with $\mathrm{A}_{14^{-}}{ }^{125} \mathrm{I}$-insulin for designated intervals, an acid-wash technique was employed to separately measure the surface-bound $\left(\mathrm{X}_{\mathrm{s}}\right)$ and intracellular $\left(\mathrm{X}_{\mathrm{i}}\right) \mathrm{A}_{14^{-}}{ }^{125} \mathrm{I}$-insulin, as well as intracellular degradation products $\left(X_{\text {deg }}\right)$ of labelled insulin. From the perfusate concentrations $\left(\mathrm{C}_{\mathrm{p}}\right)$ of $\mathrm{A}_{14^{-}}{ }^{125} \mathrm{I}$-insulin, the apparent intrinsic hepatic clearance of labelled insulin at a high dose $(0.2 \mathrm{nmol} / \mathrm{l})$ was shown to be $60 \%$ smaller than that at a low dose $(0.018 \mathrm{nmol} / \mathrm{l})$, indicating that the cellular uptake of insulin is remarkably nonlinear at the concentration range examined. From the time courses of $C_{p}, X_{s}, X_{i}$ and $X_{d e g}$, the hepatic insulin disposition was shown to be largely accounted for by the receptor-mediated endocytosis. The observed data at the low dose were analysed to estimate biochemical parameters, (i.e., total receptor number, endocytotic rate constant and intracellular degradation rate constant) according to "receptor-recycling" and "non-receptor-recycling" models, using a computer-aided optimization procedure. The "receptor-recycling" model could not only adequately explain the $C_{p}, X_{s}, X_{i}$ and $X_{\text {deg }}$ at the low dose, but also predict the $C_{p}$ at the high dose. On the other hand, a "non-receptor-re-
\end{abstract}

cycling" model, in which recycling of receptors was not assumed, could also explain the observed data at the low dose, but failed to predict the $\mathrm{C}_{\mathrm{p}}$ at the high dose, indicating that the receptor recycling process is necessary to explain the hepatic insulin clearance at high insulin concentrations, at which hepatic insulin clearance should be limited by the rate of receptor recycling. However, the applicability of our model might be limited within the physiologic insulin concentrations, because of the negative co-operativity of insulinreceptor interaction and a high-capacity, non-degradative and more rapidly recycling pathway for receptors that may occur at high concentrations of insulin. In conclusion, we have developed a mathematical model of hepatic insulin clearance and distribution under physiological conditions, including receptor binding, receptor-mediated endocytosis and receptor recycling, which has been so far demonstrated using isolated hepatocytes.

Key words: Insulin, hepatic clearance, receptor recycling, receptor-mediated endocytosis, physiological model, mouse liver perfusion.
There is a growing body of evidence that various polypeptides are taken up by their target cells via receptor-mediated endocytosis $[1,2]$. In particular, the uptake of insulin by isolated hepatocytes involves binding to receptors, endocytosis of the insulin-receptor complex, dissociation of the ligand from the receptor in an acidified endosomal compartment, and transport of the ligand to the lysosomes in which the ligand is degraded [3]. On the other hand, the internalized insulin receptors are largely recycled back to the surface of hepatocytes and reutilized $[3,4]$.

The liver plays a major role in regulating the peripheral insulin concentration due to extraction of insulin from the portal blood before entrance into the systemic circulation. Therefore, there have been a number of reports measuring hepatic extraction of insulin in in vivo and in isolated perfused livers, which demonstrate a nonlinear hepatic clearance at physiological insulin concentrations [5-7]. Moreover, it has been proposed that receptor-mediated endocytosis and its subsequent events such as receptor recycling are the major mechanisms by which receptor down-regulation is mediated [8-10]. However, there have been no explicit approaches to predict the changes in hepatic clearance and distribution of insulin, as well as the changes in surface receptor number in a physiological situation, possibly due to the lack of an adequate kinetic model.

Therefore, in the present study, we performed mouse liver perfusion experiments to examine hepatic clearance and distribution of $\mathrm{A}_{14^{-}}{ }^{125} \mathrm{I}$-insulin, combined with an acidwash technique $[11,12]$ to separately measure the surface-

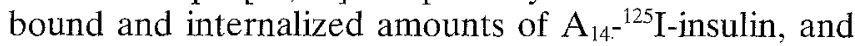
intracellular degradation products of $\mathrm{A}_{14^{-125}}{ }^{125}$-insulin in 
the liver. In order to analyse the observed data, we developed an organ model of hepatic insulin disposition, including receptor binding, receptor-mediated endocytosis and receptor recycling, namely the "receptor-recycling" model. Using this model, we attempted to predict the nonlinear hepatic elimination of insulin and the down-regulation of surface insulin receptors in the liver. The importance of receptor recycling on the hepatic insulin clearance was also discussed.

\section{Materials and methods}

\section{Materials}

Human insulin ${ }^{125} \mathrm{I}$-labelled at tyrosine- $\mathrm{A}_{14}\left(\mathrm{~A}_{14^{-}}{ }^{125} \mathrm{I}\right.$-insulin), with a specific activity of $2000 \mathrm{Ci} \cdot \mathrm{mmol}^{-1}$, was purchased from Amersham (Amersham, Buckinghamshire, UK). Crystalline porcine insulin and bovine serum albumin (BSA; Fraction V) were obtained from Sigma Chemical Co. (St. Louis, Mo, USA), and trichloroacetic acid (TCA) from Wako Pure Chemical Industries (Osaka, Japan). Bovine erythrocytes were kindly supplied from the Meat Inspection Center of Kanazawa City (Ishikawa, Japan). All other reagents were commercially available and of analytical grade. The labelled insulin was dissolved in phosphate buffered saline (PBS) containing $0.1 \%$ BSA and stored at $-20^{\circ} \mathrm{C}$ until study. The labelled insulin used was at least $98 \%$ pure as assayed by both TCA-precipitability and HPLC analysis.

\section{Animals}

Adult male ddY mice were obtained from Sankyo Laboratory Co. (Toyama, Japan) and allowed free access to standard rodent chow and water. Mice were fasted overnight before use.

\section{In situ liver perfusion}

The mice were anaesthetized with intraperitoneal pentobarbital (50 $\mathrm{mg} \cdot \mathrm{kg}^{-1}$ ), and livers were operated on according to the method of Mortimore and Tietze [13]. The livers were cyclically perfused in situ at $37^{\circ} \mathrm{C}$ in a temperature-controlled cabinet. The perfusate consisted of $10 \%$ washed bovine erythrocytes, 3\% BSA, and $3.69 \mathrm{mmol} / \mathrm{l}$ glucose in Krebs-Ringer bicarbonate (KRB) buffer ( $\mathrm{pH} 7.4$ ). Perfusate was continuously oxygenated with $95 \% \mathrm{O}_{2} / 5 \%$ $\mathrm{CO}_{2}$ by passsage through silastic tubing in an oxygenation chamber. The inlet temperature was kept at $37^{\circ} \mathrm{C}$. After operation, livers were perfused with erythrocyte-free KRB buffer in a single-pass system for $5 \mathrm{~min}$, and perfused with $12.0 \mathrm{ml}$ erythrocyte-containing KRB buffer in a closed-circuit system for $10 \mathrm{~min}$. Then, a tracer amount of $\mathrm{A}_{14^{-125}}{ }^{125}$-insulin $(0.44 \mu \mathrm{Ci}$ or $0.018 \mathrm{nmol} / \mathrm{l}$ in a final concentration), with and without $2 \mathrm{nmol} / \mathrm{l}$ of unlabelled insulin, was added in the reservoir which was constantly stirred. Subsequently, portions $(100 \mu \mathrm{l})$ of the perfusate were sampled at designated times, and centrifuged for $1 \mathrm{~min}$ in a microcentrifuge to remove erythrocytes. $\mathrm{A}_{14^{-}}$ ${ }^{125} I$-insulin in perfusate samples (without erythrocytes) was assayed by either TCA-precipitation or HPLC analysis as described later. Unless otherwise mentioned, the perfusion flow rate (including erythrocytes) was set at $1.85 \mathrm{ml} \cdot \mathrm{min}^{-1}$ and the perfusion pressure at $15-$ $18 \mathrm{~mm} \mathrm{Hg}$, using a peristaltic pump (model MP, Tokyo Rikakikai Co, Tokyo, Japan). During the 30 -min perfusion the concentrations of glutamic oxaloacetic transaminase (GOT) and glutamic pyruvic transaminase (GPT) were determined with a commercial test kit (STA-Test Wako, Wako) to assess the viability of the perfused livers.

\section{Acid-wash technique in the perfused liver}

At designated times after the addition of $\mathrm{A}_{14^{-}}{ }^{125} \mathrm{I}$-insulin into the reservoir, the acid-wash technique was performed as previously described [12]. After 20 fractions of acid-washout solution (designated as acid samples) containing acid-extractable radioactivity were sequentially collected the livers were quickly removed and a $1 \mathrm{~g}$ portion of each liver was homogenized in $4 \mathrm{ml}$ of ice-cold $1 \mathrm{~mol} / \mathrm{l}$ acetic acid containing $6 \mathrm{~mol} / \mathrm{h}$ urea. The remaining portion of the liver was weighed and counted for the total radioactivity in a $\gamma$-counter (model ARC-300, Aloka Co., Ltd., Tokyo, Japan). The tissue homogenates containing acid-resistant radioactivity were then centrifuged at $3000 \mathrm{rev} / \mathrm{min}$ for $15 \mathrm{~min}$ in a centrifuge (model RL-500SP, Tomy Seiko Co., Tokyo, Japan) at $4^{\circ} \mathrm{C}$, and the obtained supernatants (designated as tissue samples) were transferred to separate tubes for the assay of $\mathrm{A}_{14^{1}}{ }^{125} \mathrm{I}$-insulin. The percentage of radioactivity recovered in the tissue samples was more than $90 \%$.

\section{Analytical methods}

For the TCA-precipitation method, perfusate samples $(80 \mu \mathrm{l})$, acid samples $(2.5 \mathrm{ml}$ per fraction) or tissue samples $(4 \mathrm{ml})$ were mixed well with $5 \%$ TCA solution in a final concentration, kept standing at $4{ }^{\circ} \mathrm{C}$ for $30 \mathrm{~min}$, and centrifuged at $3000 \mathrm{~g}$ for $15 \mathrm{~min}$. For acid samples, $50 \mu \mathrm{l}$ of perfusate (containing $3 \%$ BSA) was added to the mixture as a precipitation carrier. The supernatants were transferred into separate tubes by aspiration. The radioactivity in the precipitates and supernatants was measured in a $\gamma$-counter.

For the HPLC analysis, each sample was deproteinized by mixing vigorously with an equal volume of ethanol, and centrifuged at $10000 \mathrm{~g}$ for $5 \mathrm{~min}$ in a microcentrifuge (MR-15A, Tomy Seiko Co.) at $4{ }^{\circ} \mathrm{C}$. The ethanol-treated supernatants were filtered through 0.45 $\mu \mathrm{m}$ millipore filters (type HV; Nihon Millipore Kogyo, Yonezawa, Japan) with the recovery of more than $80 \%$. The resultant filtrates $(100 \mu \mathrm{l})$ were loaded onto a reversed-phase HPLC column, $\mu$-Bondapak $\mathrm{C}_{18}(30 \mathrm{~cm} \times 3.9 \mathrm{~mm}$ internal diameter, Waters Associates, Inc., Milford, Mass., USA). The eluents were collected automatically and the radioactivity in each fraction $(1.0 \mathrm{ml})$ was measured in a $\gamma$-counter. The solvent delivery system, equipments, mobile phase, and elution condition are the same as described previously [12].

\section{"Receptor-recycling" model}

Considering a liver perfusion in a recirculation system, we developed an organ model of hepatic insulin clearance and distribution, in which insulin receptors are transferred between the cell surface and intracellular (vesicular) space. The structure of the model is shown in Figure 1. The differential equations describing the system are as follows:

$$
\begin{aligned}
& \frac{\mathrm{dR}_{\mathrm{s}}}{\mathrm{dt}}=\mathrm{k}_{\mathrm{ret}} \cdot \mathrm{R}_{\mathrm{i}}-\mathrm{k}_{\mathrm{end}} \cdot \mathrm{X}_{\mathrm{s}}-\mathrm{k}_{\mathrm{sp}} \cdot\left(\mathrm{R}_{\mathrm{s}}-\mathrm{X}_{\mathrm{s}}\right) \\
& \frac{\mathrm{dR}_{\mathrm{i}}}{\mathrm{dt}}=\mathrm{k}_{\mathrm{end}} \cdot X_{\mathrm{s}}+\mathrm{k}_{\mathrm{sp}} \cdot\left(\mathrm{R}_{\mathrm{s}}-\mathrm{X}_{\mathrm{s}}\right)-\mathrm{k}_{\mathrm{ret}} \cdot \mathrm{R}_{\mathrm{i}} \\
& \mathrm{V}_{\mathrm{p}} \frac{\mathrm{d} \mathrm{C}_{\mathrm{p}}}{\mathrm{dt}}=\mathrm{Q}_{\mathrm{p}} \cdot\left(\mathrm{C}_{\mathrm{e}}-\mathrm{C}_{\mathrm{p}}\right) \\
& V_{e} \frac{d C_{e}}{d t}=Q_{p} \cdot\left(C_{p}-C_{e}\right)-k_{o n} \cdot\left(R_{s}-X_{s}\right) \cdot f_{p} \cdot C_{e}+k_{\text {off }} \cdot X_{s} \\
& \frac{d X_{s}}{d t}=k_{o n} \cdot\left(R_{s}-X_{s}\right) \cdot f_{p} \cdot C_{e}-k_{\text {offi }} \cdot X_{s}-k_{e n d} \cdot X_{s} \\
& \frac{\mathrm{dX}}{\mathrm{dt}}=\mathrm{k}_{\text {end }} \cdot \mathrm{X}_{\mathrm{s}}-\mathrm{k}_{\mathrm{deg}} \cdot \mathrm{X}_{\mathrm{i}} \\
& \frac{\mathrm{d} \mathrm{X}_{\mathrm{deg}}}{\mathrm{dt}}=\mathrm{k}_{\mathrm{deg}} \cdot \mathrm{X}_{\mathrm{i}}-\mathrm{k}_{\mathrm{rel}} \cdot \mathrm{X}_{\mathrm{deg}}
\end{aligned}
$$

where $f_{p}$ denotes the fraction of insulin unbound to albumin in the perfusate. During the intracellular degradation products are not yet 


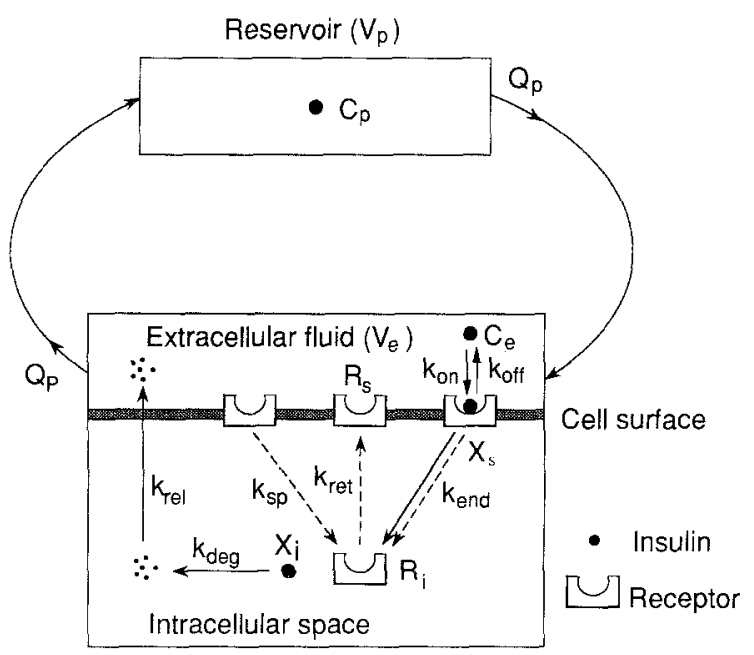

Fig. 1. The receptor-recycling model of hepatic insulin clearance and distribution. Solid and broken arrows indicate the movements of insulin and its receptors, respectively. The liver is subdivided in to the three compartments, i.e., extracellular fluid, cell surface and intracellular (vesicular) space, which are assumed to be well-mixed. Since the partition of $\mathrm{A}_{14^{-}}{ }^{125} \mathrm{I}$-insulin to erythrocytes could be neglected by the method described previously [37], the erythrocyte compartment is not considered. $R_{s}$ and $R_{i}$ defines the numbers of surface and internalized receptors, respectively. $X_{s}, X_{i}$ and $X_{\text {deg }}$ define the amounts of surface-bound insulin, internalized insulin and the intracellular degradation products of insulin, respectively. $C_{p}$ and $C_{e}$ define the concentrations in the perfusate and extracellular fluid, respectively. The rate constant $k_{\text {rel }}$ defines the release of $X_{\text {deg }}$ into the extracellular fluid. The other nomenclature is presented in Table 2 . Receptor synthesis, processing and degradation are not involved in this model, because the half-time of receptor turnover, $10 \mathrm{~h}$ [8], far exceeds the time interval $(30 \mathrm{~min})$ of the present liver perfusion. The non-specific binding of insulin to hepatocytes was neglected, because it is only about $8 \%$ of the total binding in isolated rat hepatocytes [38]. Since very little ${ }^{14} \mathrm{C}$-sucrose is taken up by perfused rat livers [39], this model confines itself to receptor-mediated endocytosis over and above fluid-phase endocytosis. The total number of mobile receptors, $R_{T}\left(=R_{s}+R_{i}\right)$, and receptor affinity, $K_{d}\left(=k_{o f f} / k_{o n}\right)$, are assumed to be constant throughout the experiment, according to the previous reports $[9,10]$.

released substantially (i.e., $\mathrm{k}_{\mathrm{deg}} \cdot \mathrm{X}_{\mathrm{i}}<<\mathrm{k}_{\mathrm{rel}} \cdot \mathrm{X}_{\mathrm{deg}}$ ), Eq. 7 can be approximated to:

$\frac{\mathrm{dX}_{\mathrm{deg}}}{\mathrm{dt}}=\mathrm{k}_{\mathrm{deg}} \cdot \mathrm{X}_{\mathrm{i}}$

\section{Data analysis}

The values of $X_{s}, X_{i}$ and $X_{\text {deg }}$ were expressed as intact $A_{14^{-125}}$ I-insulin (pmol per $g$ liver), and $C_{p}$ also as intact $A_{14^{-}}{ }^{125} I$-insulin (pmol per ml perfusate). The hepatic clearance $\left(\mathrm{CL}_{\mathrm{H}}\right)$ of $\mathrm{A}_{14}{ }^{125}$ I-insulin was calculated as follows:

$\mathrm{CL}_{\mathrm{H}}=\mathrm{k}_{\mathrm{e}} \cdot \mathrm{V}_{\mathrm{p}} / \mathrm{LW}$

where $k_{e}$ is the exponential slope of the disappearance of $A_{14^{-125}}{ }_{-}-$ insulin in the perfusate, and LW is the liver weight in grammes. Based on the clearance theory [14], the $C L_{H}$ is a function of $Q_{p}$ and the apparent intrinsic activity of hepatic elimination, $\mathrm{CL}_{\text {int.app }}$ [14]. The $\mathrm{CL}_{\mathrm{in}, \mathrm{app}}$ is given by:

$\mathrm{CL}_{\text {int,app }}=\frac{\mathrm{Q}_{\mathrm{p}} \cdot \mathrm{CL}_{\mathrm{H}}}{\left(\mathrm{Q}_{\mathrm{p}}-\mathrm{CL} \mathrm{L}_{\mathrm{H}}\right) \mathrm{f}_{\mathrm{p}}}$

\section{Determination of kinetic parameters}

Since our preliminary simulation indicated that $k_{\text {end }}, k_{\text {deg }}$ and $R_{T}$ are important parameters that determine the time courses of $C_{p}, X_{s}, X_{i}$ and $X_{\text {deg }}$ at a tracer dose, these three parameters were optimized by a procedure as described later. The other parameters (i.e., $V_{e}, V_{p}, Q_{p}$, $\mathrm{f}_{\mathrm{p}}, \mathrm{k}_{\mathrm{on}}, \mathrm{k}_{\mathrm{off}}, \mathrm{k}_{\mathrm{sp}}$ and $\mathrm{k}_{\mathrm{ret}}$ ) were measured experimentally cited or calculated from published references (Table 2). For optimization of kinetic parameters, a nonlinear least-squares regression analysis, NONLIN74 [16], was used throughout this study on a digital computer (FACOM-M360AP) at the Information Processing Center, Kanazawa University. In particular, $k_{\mathrm{sp}}$ and $\mathrm{k}_{\mathrm{ret}}$ were calculated from published data using the methods described as follows:

Calculation of $k_{\mathrm{sp}}$. The apparent endocytotic rate constant ( $k_{\text {end,app }}$ ) can be expressed as:

$\mathrm{k}_{\text {end,app }}=v \cdot \mathrm{k}_{\text {end }}+(1-v) \cdot \mathrm{k}_{\mathrm{sp}}$

where $v$ is the fraction of surface receptors occupied by insulin and given by:

$v=\frac{\mathrm{C}_{\mathrm{e}}}{\mathrm{K}_{\mathrm{d}}+\mathrm{C}_{\mathrm{e}}}$

The values of $k_{\mathrm{sp}}$ and $k_{\text {end }}$ were obtained by a nonlinear least-squares regression analysis according to Eq. 11, based on the concentrationdependent $\mathrm{k}_{\text {end.app }}$ values observed in isolated rat hepatocytes [11].

Calculation of $k_{\mathrm{ret}}$. Using $v$, Eq. 1 can be written as follows [17]:

$\frac{\mathrm{dR}_{\mathrm{s}}}{\mathrm{dt}}=\mathrm{k}_{\mathrm{ret}} \cdot\left(\mathrm{R}_{\mathrm{T}}-\mathrm{R}_{\mathrm{s}}\right)-\left[v \cdot \mathrm{k}_{\mathrm{end}}+(1-v) \cdot \mathrm{k}_{\mathrm{sp}}\right] \cdot \mathbf{R}_{\mathrm{s}}$

Since most of the mobile receptors are considered to be located at the surface of hepatocytes in fasted rats (i. e., $v \doteqdot \mathrm{O}$ ), $\mathrm{R}_{\mathrm{T}}$ can be expressed as follows, under the steady-state basal condition (i.e., $\mathrm{dR}_{\mathrm{s}} / \mathrm{dt}=0$ in Eq. 13):

$\mathrm{R}_{\mathrm{T}}=\frac{\mathrm{k}_{\mathrm{sp}}+\mathrm{k}_{\mathrm{ret}}}{\mathrm{k}_{\mathrm{Tet}}} \mathrm{R}_{\mathrm{s}, 0}$

where $R_{s, 0}^{\prime}$ represents the $R_{s}$ under the steady-state basal condition in fasted rats. On the other hand, when non-fasted rats received an intraportal injection of a large excess of unlabelled insulin (i. e., $v \doteqdot 1$ ), Eq. 13 can be transformed to:

$\frac{\mathrm{dR}_{\mathrm{s}}}{\mathrm{dt}}=\mathrm{k}_{\mathrm{ret}} \cdot \mathrm{R}_{\mathrm{T}}-\left(\mathrm{k}_{\mathrm{ret}}+\mathrm{k}_{\mathrm{end}}\right) \cdot \mathrm{R}_{\mathrm{s}}$

Integration of Eq. 15 from time 0 to $t$ and rearrangement gives:

$\ln \frac{\mathrm{R}_{\mathrm{s}, 0}-\mathrm{R}_{\mathrm{s}, \mathrm{eq}}}{\mathrm{R}_{\mathrm{s}}-\mathrm{R}_{\mathrm{s}, \mathrm{eq}}}=\left(\mathrm{k}_{\mathrm{ret}}+\mathrm{k}_{\text {end }}\right) \cdot \mathrm{t}$

where $\mathbf{R}_{s, 0}$ and $R_{s, e q}$ are the surface receptor numbers at the initial and equilibrium states, respectively, in non-fasted rats injected with intraportal dose of unlabelled insulin; and $\mathrm{R}_{\mathrm{s}, \mathrm{eq}}$ is expressed as:

$\mathrm{R}_{\mathrm{s}, \mathrm{eq}}=\frac{\mathrm{k}_{\mathrm{ret}}}{\mathrm{k}_{\text {end }}+\mathrm{k}_{\text {ret }}} \mathrm{R}_{\mathrm{T}}$

Substitution for $\mathrm{R}_{\mathrm{T}}$ in Eq. 17 according to Eq. 14 gives:

$\mathrm{R}_{\mathrm{s}, \mathrm{eq}}=\frac{\mathrm{k}_{\mathrm{sp}}+\mathrm{k}_{\mathrm{ret}}}{\mathrm{k}_{\mathrm{end}}+\mathrm{k}_{\mathrm{ret}}} \mathrm{R}_{\mathrm{s}, 0}$

Solving Eq. 16 for $\mathrm{R}_{\mathrm{s}} / \mathrm{R}_{\mathrm{s}, 0}$ and rearrangement using Eq. 18 yields:

$\frac{\mathrm{R}_{\mathrm{s}}}{\mathrm{R}_{\mathrm{s}, 0}}=(1-\alpha) \cdot \exp \left[-\left(\mathrm{k}_{\mathrm{ret}}+\mathrm{k}_{\mathrm{end}}\right) \cdot \mathrm{t}\right]+\alpha$

where $\alpha$ is expressed as:

$\alpha=\frac{\mathrm{k}_{\mathrm{ret}}+\mathrm{k}_{\mathrm{sp}}}{\mathrm{k}_{\mathrm{ret}}+\mathrm{k}_{\mathrm{end}}} \cdot \frac{R_{s, 0}^{\prime}}{R_{s, 0}}$ 
Table 1. Characteristics of the perfused mouse liver ${ }^{2}$

\begin{tabular}{|c|c|}
\hline Characteristics & Value \\
\hline Body weight (g) & $31.26 \pm 0.49(10)$ \\
\hline Liver weight (g) & $1.43 \pm 0.04(10)$ \\
\hline Endogenous insulin & $\mathrm{ND}^{\mathrm{b}}(10)$ \\
\hline Perfusion pressure $(\mathrm{mm} \mathrm{Hg})$ & $15-18$ \\
\hline GOT releasing rate constant $\left(\mathrm{min}^{-1}\right)$ & $0.0108 \pm 0.0095^{\circ}(4)$ \\
\hline GPT releasing rate constant $\left(\mathrm{min}^{-1}\right)$ & $0.0112 \pm 0.0102^{c}$ \\
\hline \multicolumn{2}{|l|}{$\mathrm{CL}_{\mathrm{H}}\left(\mathrm{ml} \cdot \mathrm{min}^{-1} \text { per liver }\right)^{\mathrm{d}}$} \\
\hline Low dose $(0.018 \mathrm{nmol} / 1)$ & 0.89 \\
\hline High dose $(2.0 \mathrm{nmol} / 1)$ & 0.52 \\
\hline \multicolumn{2}{|l|}{$\mathrm{CL}_{\text {int,app }}\left(\mathrm{ml} \cdot \mathrm{min}^{-1} \text { per g liver }\right)^{\mathrm{e}}$} \\
\hline Low dose $(0.018 \mathrm{nmol} / \mathrm{l})$ & 1.33 \\
\hline High dose $(2.0 \mathrm{nmol} / \mathrm{l})$ & 0.53 \\
\hline
\end{tabular}

${ }^{2}$ Numbers in parentheses indicate the number of perfused liver preparations from mice; ${ }^{b}$ Not detected by radioimmunoassay $(<100 \mathrm{pmol} / \mathrm{l})$; $^{\mathrm{c}}$ Expressed as the mean $\pm \mathrm{SEM}$, as assessed by a linear least-squares regression of the glutamic oxaloacetic transaminase (GOT) and glutamic pyruvic transaminase (GPT) activity (milliunits per milliliter) vs. time curves; 'Determined by Eq. 9 , using the perfusate volume $\left(V_{p}\right)$ and exponential slope $\left(k_{e}\right)$ of the disappearance of $\mathrm{A}_{14^{-1}}{ }^{125}$ I-insulin from the reservoir perfusate;

${ }^{e}$ Determined by Eq. 10, using the $\mathrm{f}_{\mathrm{p}}(=1.0), \mathrm{CL}_{\mathrm{H}}$ and $\mathrm{Q}_{\mathrm{p}}$ values

According to the report by López and Desbuquiois [10], the $R_{s, 0}^{\prime} / R_{s, 0}$ value is 1.1 , indicating that the $R_{s}$ in fasted rats is slightly $(10 \%)$ higher than that in fed rats. Therefore, one can estimate the $\mathrm{k}_{\mathrm{ret}}$ and $\mathrm{k}_{\text {end }}$ values by fitting the reported $\mathrm{R}_{\mathrm{s}} / \mathrm{R}_{\mathrm{s}, 0}$ vs time curve (i.e., in vivo down-regulation) to Eq.19, using a nonlinear least-squares regression analysis.

In order to optimize the $\mathrm{R}_{\mathrm{T}}, \mathrm{K}_{\text {end }}$ and $\mathrm{k}_{\mathrm{deg}}$, the observed data on $\mathrm{C}_{\mathrm{p}}$ $(0-30 \mathrm{~min}), X_{\mathrm{s}}, X_{\mathrm{i}}(0-20 \mathrm{~min})$ and $X_{\mathrm{deg}}(0-5 \mathrm{~min})$ at the tracer dose $(0.018 \mathrm{nmol} / 1)$ were fitted to the simultaneous differential equations (Eqs. 1-6 and 8 ) by a nonlinear least-squares regression analysis. Moreover, in order to examine the effect of receptor recycling on hepatic insulin clearance, the observed data were also fitted to the simultaneous differential equations of a "non-receptor-recycling" model, in which $\mathrm{k}_{\text {ret }}$ is set at zero.

Since the initial values of $\mathrm{k}_{\text {end }}, \mathrm{k}_{\text {deg }}$ and $\mathrm{R}_{\mathrm{r}}$ are required for the above-mentioned optimization procedure, the following methods were employed for the estimation of respective initial values.

Initial estimation of $k_{\text {end }}$ Summation of both hand sides of Eqs. 6 and 8 gives:

$$
\frac{\mathrm{d}\left(\mathrm{X}_{\mathrm{i}}+\mathrm{X}_{\mathrm{deg})}\right.}{\mathrm{dt}}=\mathrm{k}_{\mathrm{end}} \cdot \mathrm{X}_{\mathrm{s}}
$$

Therefore, the integration of Eq. 21 from time 0 to $t$ gives:

$\mathrm{X}_{\mathrm{i}}+\mathrm{X}_{\mathrm{deg}}=\mathrm{k}_{\mathrm{end}} \cdot \int_{0}^{I} \mathrm{X}_{\mathrm{s}} \mathrm{dt}$

where $\int_{0}^{t} X_{s} \mathrm{dt}$ was calculated numerically by a trapezoidal rule. Then, a plot of $\left(\mathrm{X}_{\mathrm{i}}+\mathrm{X}_{\mathrm{deg}}\right)$ vs. $\int_{0}^{t} \mathrm{X}_{\mathrm{s}} \mathrm{dt}$ should give a straight line passing through the origin, and the slope of the plot should yield an initial estimate of $\mathrm{k}_{\text {end }}$.

Initial estination of $k_{\mathrm{deg}}$. The integration of Eq. 8. from time 0 to $t$ gives:

$\mathrm{X}_{\mathrm{deg}}=\mathrm{k}_{\mathrm{deg}} \cdot \int_{0}^{t} \mathrm{X}_{\mathrm{i}} \mathrm{dt}$

where $\int_{0}^{t} \mathrm{X}_{i} \mathrm{dt}$ was calculated numerically by a trapezoidal rule. Then, a plot of $\mathrm{X}_{\mathrm{deg}}$ vs. $\int_{0}^{t} \mathrm{X}_{i} \mathrm{dt}$ should give a straight line passing through the origin, and the slope of the plot should yield an initial estimate of $k_{\text {end }}$.

Initial estimation of $R_{\mathrm{T}}$. When a ligand is taken up via receptor-mediated endocytosis, the $\mathrm{CL}_{\mathrm{int}, \mathrm{app}}$ of the ligand is expressed as follows, under a linear condition (i. e., at a tracer dose) [18]:

$\mathrm{CL}_{\text {int.app }}=\frac{\mathrm{k}_{\text {on }} \cdot \mathrm{R}_{\mathrm{s}} \cdot \mathrm{k}_{\text {end }}}{\mathrm{k}_{\text {end }}+\mathrm{k}_{\text {off }}}$

Eq. 24 gives an initial estimate of $\mathrm{R}_{s}$, by substituting the reported values of $k_{0 \pi}$ and $k_{\text {off }}$ (Table 2), the graphical estimate of $k_{\text {end }}$ calculated by Eq. 22, and the $\mathrm{CL}_{\text {int.app }}$ calculated by Eq. 10. The initial estimate of $R_{s}$ was considered as that of $R_{T}$, because most of the mobile receptors should be located at the cell surface when a tracer dose of insulin was added in the perfused liver.

\section{Prediction of the time course of $C_{\mathrm{p}}$ at a high dose ( $2 \mathrm{nmol} / \mathrm{l})$}

Using the values of $\mathrm{R}_{\tau}, \mathrm{k}_{\mathrm{end}}$ and $\mathrm{k}_{\mathrm{deg}}$ estimated above at the low dose, both the "receptor-recycling" and "non-receptor-recycling" models

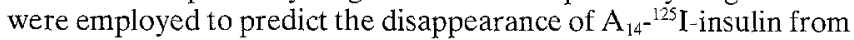
the perfusate at a high dose $(2 \mathrm{nmol} / \mathrm{l})$ to test the feasibility of these models. Two nanomolar was chosen as a high concentration of in-

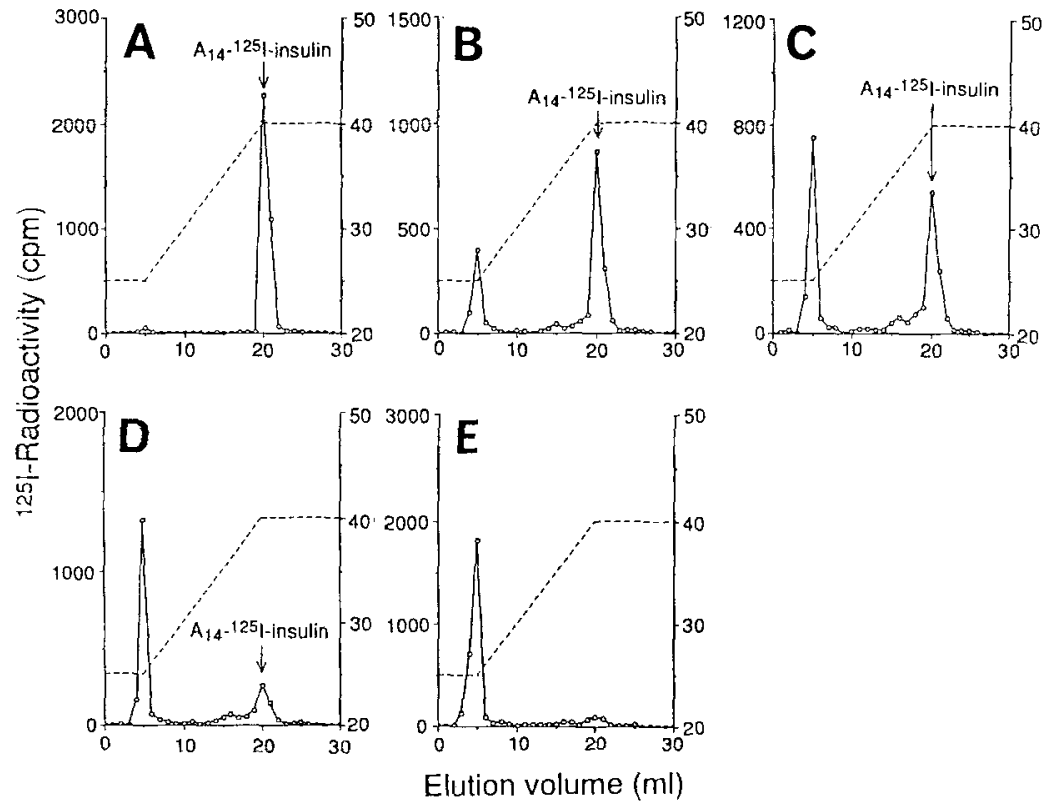

Fig. 2A-E. High performance liquid chromatography profiles of $\mathrm{A}_{14^{-125}}$ I-insulin in the perfusate after $0 \min (\mathbf{A}), 10 \min (\mathbf{B}), 15 \min (\mathbf{C})$, $20 \mathrm{~min}(\mathbf{D})$ and $30 \mathrm{~min}(\mathbf{E})$ perfusion of the mouse livers. Open circles represent ${ }^{125} \mathrm{I}$-radioactivity (cpm) in $0.8-\mathrm{ml}$ fractions eluting from $\mu$-Bondapak $\mathrm{C}_{18}$ column $(30 \mathrm{~cm} \times 3.9 \mathrm{~mm})$, which had been standardized with 3-I-L-tyrosine, $\mathrm{A}_{14^{-1}}{ }^{125} \mathrm{I}$-insulin and uniabelled porcine insulin, with the acetonitrile gradient shown by a broken line. The flow rate was set at $1.0 \mathrm{ml} \cdot \mathrm{min}^{-1}$ 


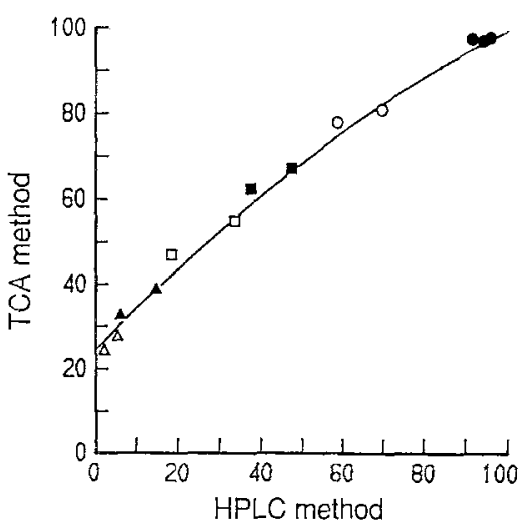

Fig. 3. Relationship of percentage of intact $\mathrm{A}_{14^{-}}{ }^{125} \mathrm{I}$-insulin between trichloroacetic acid (TCA)-precipitation and high-performance liquid chromatography (HPLC) methods in perfusates obtained $0(\bullet)$, $10(O), 15(\square), 20(\square), 30(\Delta)$ and $45(\triangle)$ min after the administration of $\mathrm{A}_{14^{-}}{ }^{125}$ I-insulin into the reservoir of cyclically perfused mouse liver. The percentage of radioactivity precipitable by TCA was calculated as (cpm in precipitate) $/[(\mathrm{cpm}$ in precipitate) $+(\mathrm{cpm}$ in supernatant)] $\times 100$, whereas the percentage of intact $\mathrm{A}_{14^{-125}}{ }^{125}$-insulin on HPLC was calculated by comparing the peak areas of radioactivity eluted from the column

sulin, since portal insulin concentrations in the post-absorptive state were reported to be $0.4-1.1 \mathrm{nmol} / \mathrm{l}[5]$.

\section{Statistical analysis}

Data were analysed by Student's $t$-test.

\section{Results}

\section{In situ liver perfusion}

Livers were perfused via the portal vein at a constant physiological pressure with a perfusate containing $10 \%$ erythrocytes as an oxygen carrier, and there was no evidence of oedema during the experiment. The characteristics of the perfused mouse livers are summarized in Table 1. The perfusion flow rate and perfusion pressure were constant during the experiments. The releasing rates of GOT and GPT are close to that of GOP reported in normal rat livers [19]. Taken together, the viability of the livers was judged to be normal and constant.

Figures $2 \mathrm{~A}-\mathrm{E}$ show typical HPLC profiles of ${ }^{125} \mathrm{I}-$ radioactivity collected from the reservoir perfusate at 0 , $10,15,20$, and $30 \mathrm{~min}$. The total radioactivity eluted from the column was almost $100 \%$ of the radioactivity loaded onto the column. A small peak eluting at 3-4 min probably represents a mixture of ${ }^{125} \mathrm{I}$ - and monoiodotyrosine, because a standard 3-I-L-tyrosine eluted as early as $3.9 \mathrm{~min}$ and very close to the salt peak $(3.1 \mathrm{~min}$ ) under the present analytical condition. The retention time of intact $\mathrm{A}_{14^{-}}{ }^{125} \mathrm{I}$-insulin was $20 \mathrm{~min}$, and it was clearly seen that $\mathrm{A}_{14^{-}}{ }^{125} \mathrm{I}$-insulin was extensively metabolized by the mouse liver during the perfusion. The identity of a small peak eluting at $16 \mathrm{~min}$ (seen in the profiles of the perfusate samples at $10-20 \mathrm{~min}$ ) is not clear from the present study,

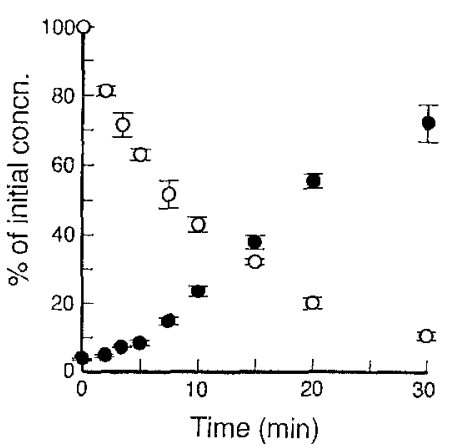

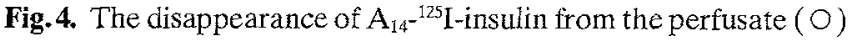
and the appearance of its degradation products in the perfusate ( $)$, after bolus administration of a tracer amount of $\mathrm{A}_{14^{-}}{ }^{125} \mathrm{I}$-insulin into the reservoir $(0.018 \mathrm{nmol} / 1$ in a final concentration) in the perfused mouse liver. Each point and vertical bar represents the mean \pm SEM from 3-13 rats (for labelled insulin) or 4 rats (for degradation products). When $\mathrm{A}_{14}{ }^{-125}$ I-insulin was perfused in the perfusion apparatus without the liver, no loss of the ${ }^{125} \mathrm{I}$-radioactivity from the reservoir was observed. Thus, the disappearance of $\mathrm{A}_{14}{ }^{125} \mathrm{I}$-insulin from the reservoir was not due to adsorption of labelled peptide to the perfusion apparatus, but to hepatic elimination. Moreover, when portions of perfusate were occasionally obtained from the perfused

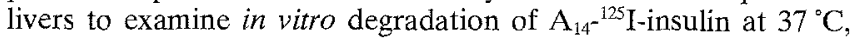
there was essentially no change in insulin concentration for up to $60 \mathrm{~min}$. Therefore, the release of proteases from the perfused livers was negligible

but it possibly represents intermediate degradation products of labelled insulin, because previous HPLC studies have demonstrated TCA-precipitable, insulin-sized intermediate products derived from enzymatic interactions of insulin with hepatocytes [20].

The relationship of the intactness of $\mathrm{A}_{14^{-}}{ }^{125}$ I-insulin in perfusate samples between the TCA-precipitation and HPLC-separation methods (Fig. 3) indicates that the TCA-precipitation overestimates the intactness of $\mathrm{A}_{14^{-}}$ ${ }^{125}$ I-insulin, as shown in a previous in vivo study [21], and further underestimates the hepatic insulin clearance. Moreover, correlation of intactness of $\mathrm{A}_{14^{-}}{ }^{125} \mathrm{I}$-insulin in the acid samples and tissue samples between the two methods was almost superimposed with the curve shown in Figure 3 (not shown). Although HPLC analysis has a greater resolving power to differentiate between the intact peptide and its metabolites compared with other methods, it is laborious to analyse many samples by HPLC. Therefore, we routinely employed the TCA-precipitation method, and the measured TCA-precipitability (\%) was converted to the percentage of intact $\mathrm{A}_{14^{4}}{ }^{125}$ I-insulin on HPLC, using the correlation between these two methods.

Figure 4 shows the disappearance of $\mathrm{A}_{14^{-1}}{ }^{125}$ I-insulin from the perfusate and the appearance of its degradation products in the perfusate, after the addition of a tracer amount of $\mathrm{A}_{14^{-}}{ }^{125}$ I-insulin in the reservoir.

\section{Acid-wash technique in the perfused liver}

When a liver was washed with ice-cold $154 \mathrm{mmol} / \mathrm{l} \mathrm{NaClfor}$ $5 \mathrm{~min}$ and then with ice-cold acidic buffer for $20 \mathrm{~min}$, two sharp peaks of ${ }^{125}$ I-radioactivity representing the acid-ex- 


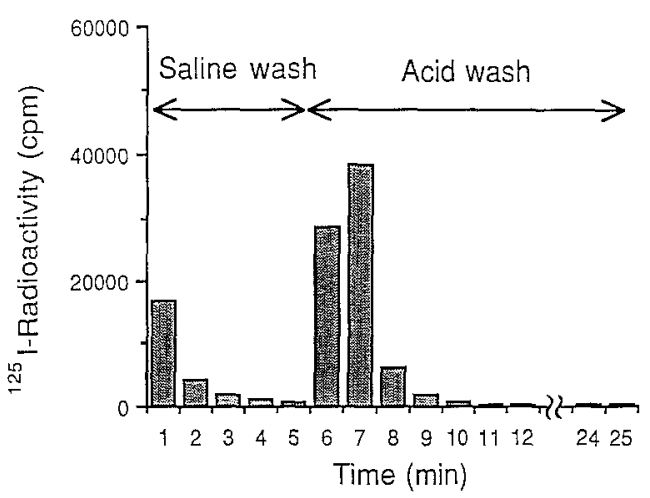

Fig.5. A representative elution profile of ${ }^{125} \mathrm{I}$-radioactivity through the outflow cannula during 5-min wash with $154 \mathrm{mmol} / \mathrm{l} \mathrm{NaCl}$ (saline) and 20-min wash with acidic buffer ( $\mathrm{pH} 3.5$ ) at $4{ }^{\circ} \mathrm{C}$, after $\mathrm{A}_{14}{ }^{125} \mathrm{I}$-insulin was perfused for $30 \mathrm{~min}$ in a cyclically perfused mouse liver. Briefly, the livers were replaced in an open-circuit system and washed for $5 \mathrm{~min}$ with ice-cold $154 \mathrm{mmol} / \mathrm{l} \mathrm{NaCl}$ at the flow rate of $2.5 \mathrm{ml} \cdot \mathrm{min}^{-1}$, to remove unbound ${ }^{125} \mathrm{I}$-radioactivity in the extracellular fluid and within the cannula. The livers were then perfused for $20 \mathrm{~min}$ with acidic buffer (acetic acid $100 \mathrm{mmol} / \mathrm{l}$; mannitol $100 \mathrm{mmol} / \mathrm{l} ; \mathrm{NaCl} 45 \mathrm{mmol} / \mathrm{l} ; \mathrm{pH} 3.5$ ) at a flow rate of $2.5 \mathrm{ml} \cdot \mathrm{min}^{-1}$
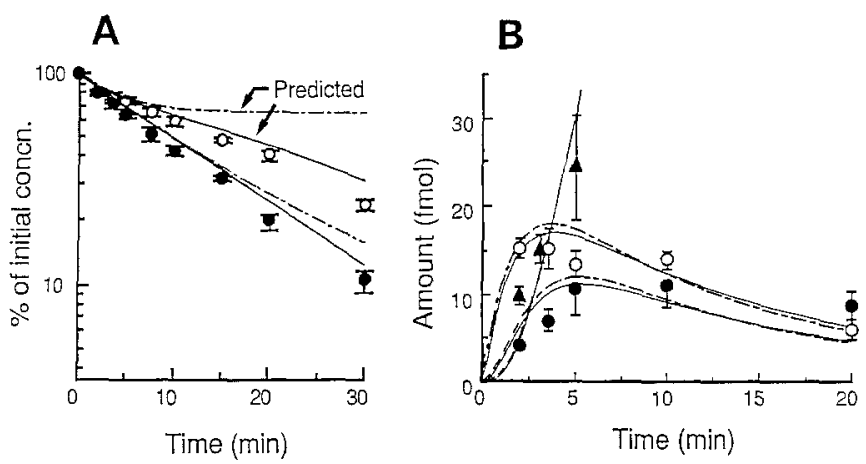

Fig. 6A,B. The clearance of $\mathrm{A}_{14^{-}}{ }^{125} \mathrm{I}$-insulin by cyclically perfused mouse livers at low $(0.018 \mathrm{nmol} / \mathrm{l} ; \mathbf{0})$ and high $(2 \mathrm{nmol} / \mathrm{l} ; 0)$ doses (in panel A). The perfusate concentrations of $\mathrm{A}_{14^{4}}{ }^{125} \mathrm{I}$-insulin at a low dose in Figure 4 are presented again in a logarithmic plot. Each point and bar represents the mean \pm SEM from $3-13$ rats (for a low dose) or 4 rats (for a high dose). In panel $\mathrm{B}$, the time-courses of acid-extractable $(O)$ and acid-resistant $(0) \mathrm{A}_{14^{-}}{ }^{125} \mathrm{I}$-insulin, as well as that of acid-resistant degradation products $(\boldsymbol{\Delta})$ of $\mathrm{A}_{14^{-}}{ }^{125} \mathrm{I}$-insulin are presented. Each point and vertical bar represents the mean \pm SEM from 4 rats. In panels A and B, solid and dashed lines show the computer-generated simulation curves using "receptor-recycling" $\left(\mathrm{k}_{\mathrm{ret}} \neq 0\right)$ and "non-receptor-recycling" $\left(\mathrm{k}_{\mathrm{ret}}=0\right)$ models of hepatic insulin clearance. The curves indicated by arrows especially provide prediction of the disappearance of $\mathrm{A}_{14^{-}}{ }^{125}$ I-insulin at a high dose $(2 \mathrm{nmol} / \mathrm{l})$, using the set of parameters determined at the low dose $(0.018 \mathrm{nmol} / \mathrm{l})$

tractable and acid-resistant $\mathrm{A}_{14^{-125}} \mathrm{I}$-insulin were sequentially eluted from the liver through the outflow cannula (Fig.5). We analyzed some acid-extractable samples by HPLC and confirmed that more than $90 \%$ of the radioactivity represents intact $\mathrm{A}_{14^{-125}}$ I-insulin (result not shown).

\section{Hepatic clearance and distribution of $A_{14^{-125}}$ I-insulin}

The time courses of $C_{p}$ at low and high doses are shown in Figure 6A. According to a linear regression analysis, the $\mathrm{k}_{\mathrm{e}}$ values were determined to be $0.0739 \pm 0.0017$ and
$0.0436 \pm 0.0015 \mathrm{~min}^{-1}$ (mean $\left.\pm \mathrm{SD}\right)$ with the correlation coefficients $(r)$ of $-0.998 \quad(p<0.001)$ and -0.995 $(p<0.001)$ at low and high doses, respectively. These $\mathrm{k}_{\mathrm{e}}$ values are significantly different from each other, as assessed by Student's $t$-test $(p<0.001)$. In a separate in vitro experiment, protein binding of $\mathrm{A}_{14^{-125}}{ }^{125}$-insulin in the perfusate (KRB buffer containing 3\% BSA) was examined using the polyethylene glycol precipitation method [22], and $f_{p}$ was determined to be 1.0. Thus, the $\mathrm{CL}_{\mathrm{H}}$ and $\mathrm{CL}_{\mathrm{int} \text {, app }}$ of $\mathrm{A}_{14^{-125}}{ }^{125}$-insulin at these doses were calculated by Eqs. 9 and 10, respectively, and are listed in Table 1 . The $\mathrm{CL}_{\text {int,app }}$ at the high dose was shown to be $60 \%$ smaller than that at the low dose, indicating that the cellular uptake of insulin is remarkably nonlinear at the concentration range examined.

Moreover, the time courses of acid-extractable and acid-resistant $\mathbf{A}_{14^{-1}}{ }^{125}$ I-insulin, as well as that of acid-resistant degradation products of $\mathrm{A}_{14^{-}}{ }^{125} \mathrm{I}$-insulin at the tracer dose are shown in Figure 6B.

\section{Kinetic analysis}

The $\mathrm{k}_{\text {sp }}$ and $\mathrm{k}_{\text {ret }}$ values were determined to be 0.022 and $0.11 \mathrm{~min}^{-1}$ by Eq.11 and Eq.19, respectively (Table 2). Using Eqs. 21 and 23, the initial estimates of $\mathrm{k}_{\text {end }}$ and $\mathrm{k}_{\mathrm{deg}}$ were given as $0.655 \pm 0.046$ and $0.693 \pm 0.024 \mathrm{~min}^{-1}$ (mean \pm SD) with the $r$ values of $0.998(p<0.05)$ and 0.999 $(p<0.05)$, respectively. Using Eq. 24, the initial estimate of $R_{T}$ was given as 11.1 pmol per liver. The $R_{T}, k_{\text {end }}$ and $k_{\text {deg }}$ were then optimized by fitting the observed data at the low dose (Fig. 6) to Eqs. 1-6 and 8 using a nonlinear leastsquares regression analysis, and are listed in Table 2.

The "receptor-recycling" model (Fig.1) could adequately explain the hepatic clearance (Fig. 6A) and distribution (Fig. 6B) of $\mathrm{A}_{14^{-}}{ }^{125} \mathrm{I}$-insulin at the low dose. The "non-receptor-recycling" model, in which no recycling of receptors $\left(\mathrm{k}_{\mathrm{ret}}=0\right)$ was assumed, could also simulate the observed data at the tracer dose, using another set of optimized parameters (i. e., $\mathrm{k}_{\mathrm{end}}$; $0.600 \pm 0.036 \mathrm{~min}^{-1}, \mathrm{k}_{\mathrm{deg}}$; $0.866 \pm 0.058 \mathrm{~min}^{-1}, \mathrm{R}_{\mathrm{T}} ; 9.93 \pm 0.57 \mathrm{pmol}$ per $\mathrm{g}$ liver, mean $\pm S D$ ). On the other hand, a good prediction of the hepatic insulin clearance at the high dose was accomplished by the receptor-recycling model, but not by the non-receptor-recycling model (Fig. 6 A).

Moreover, as can be seen from Figure 7, a computeraided prediction using the receptor-recycling model at varying initial concentrations of insulin $\left(\mathrm{C}_{\mathrm{p}}\right)$ suggests that the elimination rate constant $\left(\mathrm{k}_{e}\right)$ reduces dramatically at $\mathrm{C}_{\mathrm{p}}>1 \mathrm{nmol} / \mathrm{l}$, and that a marked reduction of surface receptors (i.e., "down-regulation") occurs also at $\mathrm{C}_{\mathrm{p}}>1 \mathrm{nmol} / \mathrm{l}$.

\section{Discussion}

Our kinetic model of hepatic insulin disposition includes several assumptions and approximations as described in the legend to Figure 1. Unique to this model is the ability to predict the changes in surface receptor number in relation to extracellular insulin as well. By use of this model, moreover, one could also examine quantitatively how the 
Table 2. Parameters used in model prediction of hepatic elimination and distribution of insulin in the perfused mouse liver

\begin{tabular}{|c|c|c|c|c|}
\hline Parameters & Symbol & Value & Units & Source \\
\hline Extracellular volume & $\mathrm{V}_{\mathrm{e}}$ & 0.55 & $\mathrm{ml}$ & experiment $^{\mathrm{a}}$ \\
\hline Perfusate volume & $\mathrm{V}_{\mathrm{p}}$ & 12.0 & $\mathrm{ml}$ & experiment \\
\hline Perfusion flow rate (without erythrocytes) & $Q_{p}$ & 1.67 & $\mathrm{ml} \cdot \min ^{-1}$ & experiment \\
\hline Insulin-receptor association rate constant & $\mathrm{k}_{\mathrm{on}}$ & $2.4 \times 10^{8}$ & $\min ^{-1} \cdot \operatorname{mol}^{-1} \cdot 1$ & ref.31 \\
\hline Insulin-receptor dissociation rate constant & $\mathrm{k}_{\text {off }}$ & 0.12 & $\min ^{-1}$ & ref. 31 \\
\hline Receptor total number & $\mathrm{R}_{\mathrm{T}}$ & $8.66 \pm 0.48$ & pmol per g liver & estimation ${ }^{\mathrm{b}}$ \\
\hline Receptor returning rate constant & $\mathrm{k}_{\text {ret }}$ & $0.11 \pm 0.02$ & $\min ^{-1}$ & calculation $^{\mathrm{d}}$ \\
\hline Intracellular degradation rate constant & $\mathrm{k}_{\mathrm{deg}}$ & $0.907 \pm 0.057$ & $\min ^{-1}$ & estimation $^{b}$ \\
\hline
\end{tabular}

${ }^{2}$ Obtained as the sum of interstitial volume $\left(\mathrm{V}_{\mathrm{IS}}\right)$ and capillary volume $\left(V_{C B}\right)$. The $V_{I S}$ was determined to be $0.55 \mathrm{ml}$ using ${ }^{14} \mathrm{C}$-inulin in mice (unpublished observation), and the $V_{C B}$ was extrapolated from the reference value in the rat liver [36] to be $0.14 \mathrm{ml}$ in the mouse liver; ${ }^{b}$ Mean $\pm S D$, estimated from the observed data on $X_{s}, X_{i}$, $X_{\text {deg }}$ and $C_{p}$ (Fig. 6) according to Eqs. $1-6$ and 8, using a nonlinear least-squares regression analysis [16]; ' Mean $\pm \mathrm{SD}$, estimated from the reported data [11] according to Eq.11 using a nonlinear least-squares regression analysis [16]; d Mean \pm SD, estimated from the reported data [10] according to Eq.19 using a nonlinear least-squares regression analysis [16]
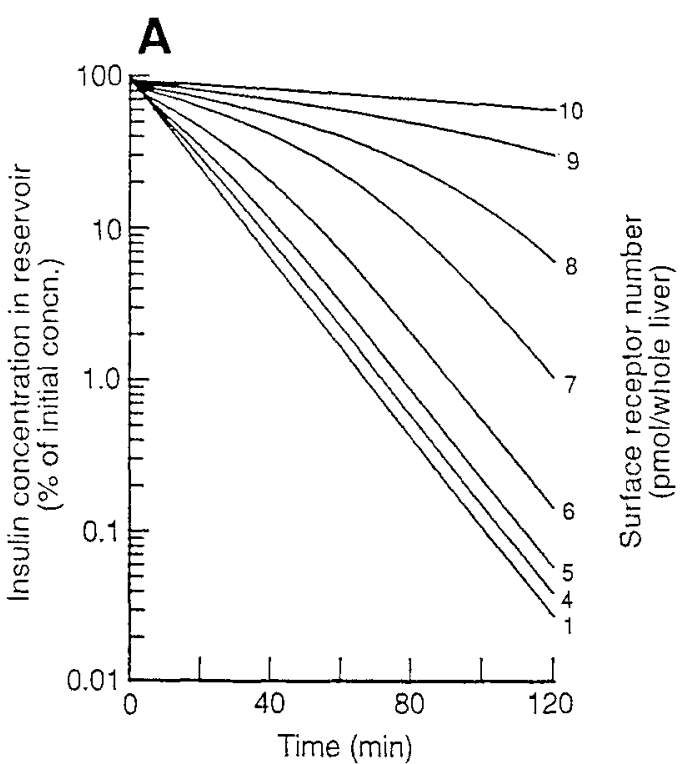

Fig. 7 A,B. Computer simulation of the time-dependent changes in the perfusate concentration of $\mathrm{A}_{14^{-}}{ }^{125}$ I-insulin (panel $\mathbf{A}$ ) and surface receptor number (panel $\mathbf{B}$ ) at varying initial concentrations of insulin in the reservoir, using the "receptor-recycling" model of hepatic insulin clearance and distribution. The numbers of 1-10 accompanying the lines correspond to the initial insulin concentrations of $0.02,0.1,0.25,0.5,1.0,2.0,4.0,6.0,10.0$ and $20.0 \mathrm{nmol} / \mathrm{l}$, respectively, used in the simulation hepatic insulin clearance would be affected by variations in the affinity of insulin-receptor interaction, which may result from mutation of insulin receptor, abnormalities of insulin processing or mutation of insulin itself. However, the applicability of our model might be limited within the physiologic insulin concentrations, because of the negative co-operativity of insulin-receptor interaction [23] and a high-capacity, non-degradative and more rapidly recycling pathway for receptors that occurs at high (supraphysiologic) concentrations of insulin [24].

Since about $50 \%$ of liver cells are not hepatocytes [25], there is a possibility that the observed clearance and distribution of $\mathrm{A}_{14^{-}}{ }^{125} \mathrm{I}$-insulin in the perfused livers are not due to specific interactions with hepatocytes. However, we could exclude this possibility, because the initial distribution of ${ }^{125}$ I-insulin was limited to the hepatocyte plasmalemma after its intraportal injection $[26,27]$, and its localization was diminished with simultaneous injection of excess unlabelled insulin [27].

In this study, an effective separation between the acidextractable and acid-resistant $\mathrm{A}_{14^{-}}{ }^{125} \mathrm{I}$-insulin was per- formed by the acid-wash technique. Moreover, our preliminary experiments show that ${ }^{125}$ I-radioactivity in both the acid-extractable and acid-resistant samples considerably decreased in the presence of $1 \mu \mathrm{mol} / \mathrm{l}$ unlabelled insulin in the perfusate, and ${ }^{125}$ I-radioactivity in the acidresistant samples markedly decreased in the presence of $250 \mu \mathrm{mol} / \mathrm{l}$ of an endocytosis inhibitor, phenylarsine oxide (results not shown). These lines of evidence suggest that the observed acid-resistant $\mathrm{A}_{14^{-}}{ }^{125}$ I-insulin largely represents the intracellular $\mathrm{A}_{14^{-}}{ }^{125} \mathrm{I}$-insulin, and that the acidextractable ${ }^{125}$ I-radioactivity was bound to surface receptors.

As shown in Figure 6B, the peak of the intracellular $\mathrm{A}_{14^{-}}{ }^{125} \mathrm{I}$-insulin was several minutes later than that of surface-bound $\mathrm{A}_{14^{-}}{ }^{125} \mathrm{I}$-insulin, suggesting that the surfacebound ligand may be regarded as the substrate of endocytosis. Moreover, the increase of degradation products of $\mathrm{A}_{14^{12}}{ }^{125} \mathrm{I}$-insulin in the reservoir was small for the first $5 \mathrm{~min}$, and rapidly increased thereafter. Since the lag time for $\mathrm{A}_{14^{-}}{ }^{125}$ I-insulin in the reservoir to reach the inlet of the organ was subtracted from the sampling time, this is not 
due to an access delay of $\mathrm{A}_{14^{-}}{ }^{125} \mathrm{I}$-insulin to the liver. Therefore, that the major site of insulin degradation is in an intracellular compartment but not in an extracellular compartment is suggested in this study, as reported by other workers $[28,29]$. Taken altogether, the results obtained indicate that the hepatic insulin clearance is largely accounted for by the receptor-mediated endocytosis in the perfused mouse livers, and supports the feasibility of the present model of hepatic insulin clearance and distribution.

As listed in Table 2, the value of $R_{T}$ was estimated to be $8.66 \mathrm{pmol}$ per $\mathrm{g}$ liver, that is 44000 sites per cell, assuming that the number of hepatocytes per liver in mice is the same as that in rats, $1.3 \times 10^{8}$ cells per $g$ liver [30]. This $R_{T}$ value is in good agreement with the $R_{5}$ for isolated rat hepatocytes in vitro, e. g., 45000 [31] and 50100 sites per cell [32], in which almost all mobile receptors may be located on the surface of isolated cells due to the absence of extracellular insulin during preparation. On the other hand, the estimated $k_{\text {end }}$ is somewhat greater than that reported for isolated rat hepatocytes, $0.38 \mathrm{~min}^{-1}$ [24].

A good agreement between the observed and simulated values of $\mathrm{C}_{\mathrm{p}}, \mathrm{X}_{\mathrm{s}}, \mathrm{X}_{\mathrm{i}}$ and $\mathrm{X}_{\mathrm{deg}}$ at the low dose by both the receptor-recycling and non-receptor-recycling models suggests that internalization process, not receptor recycling, is important for the hepatic insulin clearance at low insulin concentrations. On the other hand, the predictions of $\mathrm{C}_{p}$ at the high dose by these models suggest an important role of receptor recycling in the hepatic insulin clearance at high insulin concentrations, at which surface receptors are considered to be largely occupied. It probably, therefore, follows that when the $\mathbf{R}_{\mathrm{s}}$ is considerably decreased at high insulin doses, the hepatic insulin clearance should be limited by the rate of receptor recycling. We propose, therefore, that the rate-limiting step of hepatic intrinsic clearance of insulin is the internalization process at low insulin concentrations, but moved to the receptor reycling process at relatively high concentrations. This is consistent with the fact that chloroquine, which blocks receptor recycling via preventing intravesicular acidification [2], did not alter the disappearance of $\mathrm{A}_{14}{ }^{125}$ I-insulin (tracer dose) in the perfused rat livers [33]. Thus, a dynamic "receptor-recycling" model could be advantageous to a static model of insulin clearance [34] that assumes a constant surface receptor number, because the latter model cannot evaluate the significance of receptor recycling on hepatic insulin clearance. From the computer simulation, it was predicted that the changes in the $\mathrm{k}_{\mathrm{e}}$ (as well as $\mathrm{CL}_{\mathrm{H}}$ ) and $\mathrm{R}_{\mathrm{s}}$ are not so sensitive to the initial concentrations of less than $1 \mathrm{nmol} / 1$ and more than $10 \mathrm{nmol} / 1$, while very sensitive to those of $1-10 \mathrm{nmol} / \mathrm{l}$. This is in agreement with the report that the hepatic extraction of insulin is reduced with increasing endogenous insulin secretion after pancreatic stimulation with oral glucose [35], when the portal vein insulin is reported to be 4.5$7.0 \mathrm{nmol} / 1$ [5]. However, further study should be focussed on the validation of the model at a wider concentration range of insulin, and, if necessary, a more detailed modelling of hepatic insulin disposition should be performed to accommodate a full dose response curve as shown in Figure $7 \mathrm{~A}$.
In conclusion, we have developed a "receptor-recycling" model of hepatic insulin clearance, based on a physiological and biochemical approach. The model could afford to predict not only the nonlinear clearance and distribution of insulin in the perfused liver, but also the change in surface receptor number, in a quantitative manner. The mathematical methods described here should be useful to analyse the receptor-mediated endocytosis of other ligands in an intact organ.

Acknowledgements. This study was supported by a Grant-in-Aid for Scientific Research from the Ministry of Education, Science and Culture of Japan, Project Research Fund from the Graduate School of Natural Science and Technology, Kanazawa University, and grants from the Nakatomi Foundation and Takeda Science Foundation.

\section{References}

1. Gorden F, Carpentier JL, Fan JY, Orci L (1982) Receptor mediated endocytosis of polypeptide hormones: mechanism and significance. Metabolism 31: 664-669

2. Wileman T, Harding C, Stahl P (1985) Receptor-mediated endocytosis. Biochem J 232: 1-14

3. Sonne O (1988) Receptor-mediated endocytosis and degradation of insulin. Physiol Rev 68: 1129-1196

4. Fehlman M, Carpentier JL, Obberghen EV et al. (1982) Internalized insulin receptors are recycled to the cell surface in rat hepatocytes. Proc Natl Acad Sci USA 79: 5921-5925

5. Misbin RI, Merimee TJ, Lowenstein JM (1976) Insulin removal by isolated perfused rat liver. Am J Physiol 230: 171-177

6. Tranberg KG (1979) Hepatic uptake of insulin in man. Am J Physiol 237: E509-E518

7. Polonsky K, Jaspan J, Emmanouel D, Holmes K, Moossa AR (1983) Differences in the hepatic and renal extraction of insulin and glucagon in the dog: evidence for saturability of insulin metabolism. Acta Endocrinol 102: 420-427

8. Krupp M, Lane MD (1981) On the mechanism of ligand-induced down-regulation of insulin receptor level in the liver cell. J Biol Chem 256: 1689-1694

9. Desbuquois B, Lopez S, Burlet H (1982) Ligand-induced translocation of insulin receptors in intact rat liver. $\mathrm{J}$ Biol Chem 257 : $10852-10860$

10. López S, Desbuquois B (1987) Insulin-related changes in the subcellular distribution of insulin receptors in intact rat liver: Effects of acute hypoinsulinemia induced by diazoxide, somatostatin, and xylazine. Endocrinology 120: 1695-1702

11. Draznin B, Trowbridge M, Ferguson L (1984) Quantitative studies of the rate of insulin internalization in isolated rat hepatocytes. Biochem J 218: 307-312

12. Sato H, Yoshioka K, Terasaki T, Tsuji A (1991) Receptor-mediated endocytosis of $\mathrm{A}_{14^{-}}{ }^{125} \mathrm{I}$-insulin by the nonfiltering perfused rat kidney. Biochim Biophys Acta 1073: 442-450

13. Mortimore GE, Tietze F (1959) Studies on the mechanism of capture and degradation of insulin- $\mathrm{I}^{131}$ by the cyclically perfused rat liver. Ann New York Acad Sci 82: 329-337

14. Wilkinson GR, Shand DG (1975) A physiological approach to hepatic drug clearance. Clin Pharmacol Ther 18: 377-390

15. Sato H, Sugiyama Y, Miyauchi S, Sawada Y, Iga T, Hanano M (1986) A simulation study on the effect of a uniform diffusional barrier across hepatocytes on drug metabolism by evenly and unevenly distributed uni-enzyme in the liver. J Pharm Sci 75: 3-8

16. Metzler CM, Elfring GL, McEwen AJ (1974) A package of computer programs for pharmacokinetic modeling. Biometrics 30 : 562

17. Standaert ML, Pollet RJ (1984) Equilibrium model for insulininduced receptor down-regulation. Regulation of insulin recep- 
tors in differentiated BC3H-1 myocytes. J Biol Chem 259: 23462354

18. Sato H, Terasaki T, Okumura K, Tsuji A (1991) Effect of receptor up-regulation on insulin pharmacokinetics in streptozotocintreated diabetic rats. Pharm Res 8: 563-569

19. Cox JW, Cox SR, VanGiessen G, Ruwart MJ (1985) Ibuprofen Stereoisomer hepatic clearance and distribution in normal and fatty in situ perfused rat liver. J Pharmacol Exp Ther 232: 636-643

20. Hamel FG, Posner BI, Bergeron JJM, Frank BH, Duckworth WC (1988) Isolation of insulin degradation products from endosomes derived from intact rat liver. J Biol Chem 263: 6703-6708

21. Sato H, Tsuji A, Hirai K, Kang YS (1990) Application of HPLC in disposition study of $\mathrm{A}_{14}{ }^{-125}$ I-labelled insulin in mice. Diabetes 39: $563-569$

22. Sato H, Sugiyama Y, Sawada Y, Iga T, Hanano M (1985) Binding of radioiodinated human $\beta$-endorphin to serum proteins from rats and humans, determined by several methods. Life Sci 37: 1309-1318

23. De Meytes P, Bianco AR, Roth J (1976) Site-site interactions among insulin receptors. Characterization of the negative cooperativity. J Biol Chem 251: 1877-1888

24. Levy JR, Olefsky JM (1987) The trafficking and processing of insulin and insulin receptors in cultured rat hepatocytes. Endocrinology 121:2075-2086

25. De Pierre JW, Karnovsky ML (1973) Plasma membranes of mammalian cells. J Cell Biol 56: 275-303

26. Bergeron JJM, Levine G, Sikstrom R, O'Shaughnessy D, Kopriwa B, Nadler NJ, Posner BI (1977) Polypeptide hormone binding sites in vivo: initial localization of ${ }^{125}$ I-labelled insulin to hepatocyte plasmalemma as visualized by electron microscope radioautography. Proc Natl Acad Sci USA 74: 5051-5055

27. Bergeron JJM, Sikstrom R, Hand AR, Posner BI (1979) Binding and uptake of ${ }^{125} \mathrm{I}$-insulin into rat liver hepatocytes and endothelium. An in vivo radioautographic study. J Cell Biol 80: 427443

28. Williams FG, Johnson DE, Bauer GE (1990) [ $\left.{ }^{125} \mathrm{I}\right]$-Insulin metabolism by the rat liver in vivo: evidence that a neutral thiol-protease mediate rapid intracellular insulin degradation. Metabolism 39: 231-241

29. Donner DB (1982) Receptor- and non-receptor-mediated uptake and degradation of insulin by hepatocytes. Biochem J 208: 211-219
30. Seglen PO (1973) Preparation of rat liver cells. III. Enzyme requirements for tissue dispersion. Exp Cell Res 82: 391-398

31. Gammeltoft S, Kristensen L $\varnothing$, Sestoft L (1978) Insulin receptors in isolated rat hepatocytes. J Biol Chem 253: 8406-8413

32. Frank HJL, Davidson MB, Serbin PA (1981) Insulin binding and action in isolated rat hepatocytes: evidence for spare receptors. Metabolism 30: 1159-1164

33. Ward WF, Moss AL (1985) Effects of lysosomal inhibitors on ${ }^{125}$ I-insulin and ${ }^{125} \mathrm{I}$-asialofetuin degradation by the isolated, perfused rat liver and isolated rat hepatocytes. Diabetes 34: 446-451

34. Jones RH, Sönksen PH, Boroujerdi MA, Carson ER (1984) Number and affinity of insulin receptors in intact human subjects. Diabetologia 27: 207-211

35. Eaton RP, Allen RC, Schade DS (1983) Hepatic removal of insulin in normal man: dose response to endogenous insulin secretion. J Clin Endocrinol Metab 56: 1294-1300

36. Tsuji A, Yoshikawa T, Nishide K et al. (1983) Physiologically based pharmacokinetic model for $\beta$-lactam antibiotics I: tissue distribution and elimination in rats. J Pharm Sci 72: 1239-1252

37. Sato H, Sygiyama Y, Sawada X, Iga T, Hanano M (1987) Physiologically based pharmacokinetics of radioiodinated human $\beta$-endorphin in rats. An application of the capillary membranelimited model. Drug Metab Dispos 15: 540-550

38. Terris S, Steiner DF (1975) Binding and degradation of ${ }^{125} \mathrm{I}$-insulin by rat hepatocytes. J Biol Chem 250: 8389-8398

39. Surmacz CA, Wert, Jr. JJ, Ward WF, Mortimore GE (1988) Uptake and intracellular fate of $\left[{ }^{14} \mathrm{C}\right]$ sucrose-insulin in perfused rat livers. Am J Physiol 255: C70-C75

Received: 21 January 1991

and in revised form: 15 May 1991

Dr. A. Tsuji

Faculty of Pharmaceutical Sciences

Kanazawa University

Takara-machi 13-1

Kanazawa 920

Japan 